\title{
A teleházak árképzésének és földrajzi elhelyezkedésének összefüggései
}

A teleházak Magyarországon több mint egy évtizedes múltra tekintenek vissza. A tanulmány a teleházak árképzésének és földrajzi elhelyezkedésének összefüggéseit vizsgálja. Az eredmények szerint a teleházak életében az árképzés sokadrangú kérdés, gyakorlatilag független minden más jellemzőtől. Ez azt jelenti, hogy nincs tudatos, összehangolt árpolitika, a teleházak véletlenszerűen, minden más tényezőtől függetlenül állapítják meg áraikat. A jelenség oka abban keresendő, hogy a teleházak szolgáltatásból származó árbevétele viszonylag kevés, teljes múködési költségeiknek csak a felére-harmadára elegendő. A pályázatokból, támogatóktól származó egyéb bevételek sokkal fontosabbak számukra. A teleházak non-profit intézmények, nem is törekedhetnek nyereséges működésre, gazdasági megítélésükben tehát mindenképpen figyelembe kell venni a helyi társadalom életében és általános közérzetében betöltött szerepüket is.

Kulcsszavak: teleház, vidékfejlesztés, fenntarthatóság, gazdaságosság

\section{Szerzői információ:}

\section{Hohl Ferenc}

Agronómus és informatikus, a Gödöllooi Szent István Egyetemen szerzett gazdasági agrármérnöki és mérnöktanári diplomát. 2002-tôl PhD-hallgató az egyetem Vidékfejlesztési és Szaktanácsadási Intézetében. 2004 óta internettechnológiával és szoftverfejlesztéssel foglalkozik. Egyik fố kutatási területe a teleházak helyzete. Fốként a kisebbségek és a hátrányos helyzetú közösségeknek az informatikai fejlődéssel összefüggố témáiban publikál. Legújabb közleménye ebben a témában A teleházak hatás-és hatékonyságvizsgálatának elméleti megalapozása címmel jelent meg. E-mail: hohl.ferenc@netgo.hu

Így hivatkozzon erre a cikkre:

Hohl Ferenc. „A teleházak árképzésének és földrajzi elhelyezkedésének összefüggései”. Információs Társadalom VI, 2. szám (2006): 98-108. https://dx.doi.org/10.22503/inftars.VI.2006.2.10

A folyóiratban közölt müvek a Creative Commons Nevezd meg! - Ne add el! - Így add tovább! 4.0 Nemzetközi Licenc feltételeinek megfelelően használhatók. 
Hohl Ferenc

\section{A teleházak árképzésének és földrajzi elhelyezkedésének ös s zefüggései}

\section{Teleházak Magyarországon}

A teleházak az elmúlt néhány évben jelentôs fejlódésen mentek keresztül. A 90-es évek végére a teleházmozgalom intézményesedett és országos hálózatot hozott létre, amely több mint 400 teleházzal rendelkezik. A teleházak témakörét számos kutatás és tanulmány vizsgálta már, de a teleházak gazdasági jellemzốivel kevés tanulmány foglalkozott. Ennek oka fóleg a szerzók szemléletmódjában keresendô, akik elsốsorban a társadalmi hatásokat vizsgálták, és nem elemezték részletesen a gazdasági kérdéseket (Bártfai, 2002; Bihari, 1999; Erdősi, 1992). A teleházak hosszú távú sikeres múködésének azonban elengedhetetlen feltétele gazdasági jellemzóik, gazdasági fenntarthatóságuk megvizsgálása is. Nemzetközi tapasztalatok szerint a teleházak kétharmada a múködés elsô három évében bezár (Gáspár-Takáts, 1997). ${ }^{1}$ Ez a tény a mozgalom sikerességét alapjaiban veszélyezteti.

A gazdasági fenntarthatóság szempontjából a bevétel-költség arány döntő fontosságú. A bevételek egy részét az árbevétel adja, az árbevétel nagyságát pedig az illető szervezet vagy teleház árképzése határozza meg. A teleházak árképzése tehát a gazdasági fenntarthatóság vizsgálatának fontos eleme.

\section{Mi a teleház?}

A teleház infrastrukturális hátteret nyújt a helyi humáneróforrások fejlesztéséhez. Mit jelent ez? Azt jelenti, hogy irodai-számítástechnikai szolgáltatásokat ad a helybelieknek, de ezen túlmenóen biztosítja tudásuk, képzettségük fejlesztésének lehetôségét is, tanfolyamok, rendezvények útján. Más megfogalmazás szerint a teleház egy helyiség, ahol közösségi hozzáférési lehetôség van az információs és kommunikációs technológiai eszközökhöz (Proenza, 2001). A teleház többfunkciós, nyitott profilú kisközösségi információs és telekommunikációs szolgáltató központ (Bihari, 1999: 86).

A teleházak alapításának egyik fő célja az, hogy helyet biztosítsanak a közösségi hozzáféréshez (Gáspár és tsai, 2003), tehát ha valaki nem rendelkezik megfelelő számítógéppel és internetkapcsolattal, legyen egy hely, ahol ezekhez hozzájut. Egy teleház azonban nem elégedhet meg azzal, hogy számítógépet és hozzáférést biztosít a helyi közösségnek, mivel az internetet használók száma egyre növekszik, ${ }^{2}$ elóbb-utóbb min-

${ }^{1} 2003$ nyaráig az addig létesített 491 teleházból mintegy 129 (26\%) szűnt meg. (Forrás: Teleház Szövetség, 2003. évi adatbázis.)

${ }^{2}$ Fokozódó internethasználat az alacsonyabb státusú rétegekben (2005)

http://www.terminal.hu/newsread.php?id=30205003054407 
denkinek saját internet-hozzáférése és számítógépe lesz. Vagyis annak a teleháznak, amelyik fenn akar maradni, túl kell lépnie az egyszerú alapszolgáltatások nyújtásán, és komplex, a közösséget is érdeklő szolgáltatásokat kell nyújtania. A teleház csak akkor lehet hosszú távon sikeres, ha felvállalja, hogy megpróbálja megoldani az embereket érintő problémákat, legyen szó akár egy adóbevallás elkészítéséról vagy egy hivatalos levél megírásáról.

\section{A kutatás célja}

Jelen tanulmány célja az árképzés szerepének tisztázása a teleházak múködésében, külsố körülmények - a földrajzi elhelyezkedés - figyelembevételével. A vizsgálat elsősorban arra keresett választ, hogy hogyan és mennyire befolyásolja a teleházak múködését a teleházak árképzése.

\section{A vizsgálatok módszerei}

A kutatáshoz felhasznált adatok két forrásból származnak: az egyik a Magyar Teleház Szövetség (MTSZ) adatbázisa, a másik saját kutatómunka eredménye. A felmérések fố célja az volt, hogy háttéranyagot biztosítsanak a teleházak és a teleházmozgalom értékeléséhez. A teleházak értékeléséról a Teleház Szövetség minốségbiztosítási dokumentuma a következóket állapítja meg: „Magyarországon mind ez idáig nem foglalkoztunk módszeresen a teleházak múködésének eredményességével, hatásosságával. A minôségbiztosításnak ez az alapkérdése. Nemcsak egy teleház, de az egész mozgalom értékelésre vár e tekintetben" (Teleház Minőség Program, 1999: 4).

Az elmúlt években több tanulmány is megjelent, amelyek a teleházak helyzetét vizsgálták (Kas-Mimi, 2001; Laczkó-Soltész, 2003). A teleházak értékelésével egyre több szakértố foglalkozik, de vannak olyan területei az értékelésnek, amelyek felderítése viszonylag nehézkes, nem kellően támogatott. A teleházak gazdasági értékelése, a múködés, a gazdaságosság vizsgálata ezek közé a területek közé tartozik. Kutatásaim egy része ennek a gyengén kutatott területnek a tüzetesebb vizsgálatára irányul, ezen belül a teleházak árképzésének vizsgálata szervesen illeszkedik a kutatási célokhoz. A saját adatbázisom a 2003/2004. tanév során állt fel, alapja egy kérdőívvel elvégzett felmérés, amely megyénként öt-öt, országos szinten 95 teleházat érintett. A felmérés a következố fóbb területekre terjedt ki:

1. A teleházak múködési jellemzôi

2. A teleház hogyan és milyen szinten integrálódott a helyi közösségbe

3. A teleházak tulajdonviszonyai

4. A teleház és a munka, távmunka viszonya

5. A teleház és az oktatás, távoktatás viszonya

6. A teleházak szolgáltatásai, a szolgáltatások összehasonlítása

7. A teleházak humánerôforrásainak felmérése 
$\mathrm{Az}$ adatfelvétel személyesen, levélben és e-mailben történt. A visszaérkezési arány $100 \%$-os volt, tehát mind a 95 teleházban sikeres volt az adatfelvétel. A visszaérkezési arány elérése azonban néhány teleház esetében szükségessé tette a felmérésból való kizárást, ezek helyett új teleház került a kutatásba. Bár a felmérés egyéb okok miatt nem lehetett reprezentatív, az ország teleházainak jelentôs részét (több mint 20\%-át) képviseli, és a maga nemében a 2001. évi teleház-monitoring mellett az egyik legnagyobb merítésú teleházakra vonatkozó kutatás.

Az adatbázis adatainak feldolgozása Excel és SPSS programok segítségével történt. Az eredmények egy része numerikus, más része szöveges információkból állt eló, ezért a feldolgozás statisztikai számításokat (alapstatisztikák, kereszttáblák, indexképzés) és szövegelemzést egyaránt igényelt. A kutatás két lépcsóben történt. Az elsố lépcsóben az eredmények az MTSZ 2004. évi nyilvántartásának és a KSH TSTAR 2003. évi adatainak összekapcsolásából származnak. Az MTSZ 2004. évi nyilvántartása 541 teleházról, a TSTAR 2003. évi kiadása pedig 2883 faluról tartalmaz információkat.

Az elemzések során az elsố lépésben szükség volt annak meghatározására, hogy melyek azok a tényezók, amelyekkel jellemezhetô egy település, ahol van, és ahol nincs teleház. Ennek megállapításához sor került a fent említett két adatbázis összekapcsolására, majd a szóba jöhető olyan számszerúsíthetô tényezók meghatározására, amelyek jól jellemeznek egy települést. Összesen 19 olyan jellemző volt, amely a TSTAR segítségével minden egyes településre pontosan kiszámolható. ${ }^{3}$ A szakirodalom szerint (Hahn; Nemes-Nagy és tsai) több más mutató is van, ami alkalmas egy-egy település fejlettségének, jellemzőinek leírására. Ezek közül azonban sok nem állt rendelkezésre, vagy jellegénél fogva nem volt alkalmas az elemzésben való felhasználásra. Ezt követôen egy diszkriminanciaanalízis elvégzése következett. A vizsgálatok csak és kizárólag azokra a teleházakra korlátozódtak, melyek falvakban vagy községekben vannak, a városi teleházak (nagyjából 20\%) kimaradtak az elemzésból. Az adatbázis az említett 19 mutatón kívül kibővült még három adattal: az egyik a $H I$, vagyis a humán index, a másik a városoktól való távolság, ${ }^{4}$ a harmadik pedig a kistérség vidékiség jellege. ${ }^{5}$

A HI alkalmazása a HDI (Human Development Index) ${ }^{6}$ magyarországi viszonyokra adaptált módszere, amit a Szent István Egyetem kutatói ültettek át hazai viszonyokra (Obádovics-Kulcsár, 2003). A HDI kifejlesztésének célja az országok, társadalmi csoportok, eltérố élethelyzetek közötti különbségek jellemzése volt. A HI kistérségi, megyei és régiók szerinti bontásban áll rendelkezésre, településszinten nem. A település $H I$-értékének megállapításához a kistérség $H I$-értéke szolgált alapul, ami valamelyest torzíthat az összképen, de a lényegi pontokon nem változtat. Ugyanez vonatkozik a te-

${ }^{3}$ Ezek a következók: népsúrúség, születés, halálozás, korcsoportos megoszlás, öregségi index, természetes szaporodás, fogyás, vándorlási egyenleg, lakás-ellátottság, személygépkocsi-ellátottság, rendszeres szociális segélyben részesülók aránya, munkanélküliségi arány, tartósan munkanélküliek aránya, aktív korúak aránya, múködő gazdasági szervezetek száma, múködő nonprofit szervezetek száma, múködő vállalkozások száma a mezőgazdaságban, kereskedelmi üzletek száma, ISDN-vonalak száma, vonalastelefon-ellátottság.

${ }^{4}$ Kategóriái: nagyváros (50 e fö felett), nagyváros 30 km-en belül, nagyváros 30 km-en kívül.

${ }^{5}$ A vidékiség jellegének megállapítása az $O E C D$ által kialakított módszerrel történt.

${ }^{6}$ A HDI-t az Egyesült Nemzetek Fejlesztési Programja keretében dolgozták ki. Széles körben alkalmazzák, 1990 óta 160 országra határozzák meg, minden évben újraszámolva értékeit. 
lepülés vidékiség jellegének megállapítására is. Ez a három adat a késóbbiekben számos elemzés alapjául szolgált, többek között az árak területi elemzéséhez is kiindulópontot biztosított.

A teleházakkal foglalkozó szakírók szerint a teleházak az elmaradottabb, fejletlenebb településeken jönnek létre (Bihari, 1999; Gáspár-Takáts, 1997). A mélyebb elemzéshez ellenôrizni kellett ennek az állításnak az igazságtartalmát. Az állítás ellenőrzése a teleházak megyénkénti és régiónkénti aggregálásával és a $H I$ összevetésével történt. A kapott eredmények a késóbbiekben a további elemzések alapjait biztosították.

A kutatás második lépcsôjében a saját adatbázis elemzésére került sor. Itt a viszonylag alacsony elemszám miatt csupán alapstatisztikák készültek. A kutatás elsô fordulójában elvégzett elemzések az összes magyarországi teleházra vonatkoznak (HI-érték, vidékiség jellege, városoktól való távolság, diszkriminanciaanalízis), míg a második fordulóban elvégzett elemzések csak a megvizsgált 95 teleházra (árindex).

\section{Kutatási hipotézisek}

Az elemzések több kérdésre is választ kerestek. Fontos annak megállapítása, hogy melyek azok a tényezók, amelyek jellemeznek egy-egy olyan települést, ahol teleház is található, és vajon igaz-e, hogy a teleházakat olyan településeken hozzák létre, amelyek erre valóban rászorulnak. Továbbgondolva a kapott eredményeket, ezek a tényezók vajon hatással vannak-e a teleházak árképzésére, és ezen keresztül a teleházak gazdasági múködésére? Van-e összefüggés a teleházak földrajzi elhelyezkedése és árképzése között? Van-e összefüggés a teleház múködési tényezôi és a teleház árképzése között? Ezeknek a kérdéseknek a megválaszolása létfontosságú lehet, mert meghatározhatják a teleházak fenntarthatóságát. Elképzelhetô ugyanis, hogy a teleházak a jobb gazdasági, demográfiai adottságú területekre települnek, ahol nagyobb a fizetóképes kereslet, és könnyebb gazdaságilag fenntartani egy teleházat.

\section{A teleházak földrajzi elhelyezkedése}

Igaz-e, hogy a teleházak ott jönnek létre, ahol a legnagyobb szükség van rájuk? Ez a kérdés a teleházak magas száma miatt félig-meddig megválaszolja önmagát, hiszen ha elóbb-utóbb minden településen lesz teleház, nyilvánvalóan olyan településen is lesz, amelyik annyira nem szorulna rá. A vizsgálatok szerint a $H I$-érték és a teleházak létesítése között nincs közvetlen összefüggés, tehát az adott település fejlettsége nem áll összefüggésben a teleház megjelenésével. Ugyanakkor elmondható az is, hogy településeink nagy része (a HI-érték szerint) közepes és alacsony fejlettségú, a teleházak eloszlása pedig ezt a mintát követi. Vagyis a teleházak jó része szintén közepes és alacsony HI-értékủ településen található (79\%). Mivel azonban a teleházak eloszlása a települések eloszlását követi, csakugyan igaz az, hogy a $H I$ érték és a teleházak megjelenése között nincs összefüggés. 


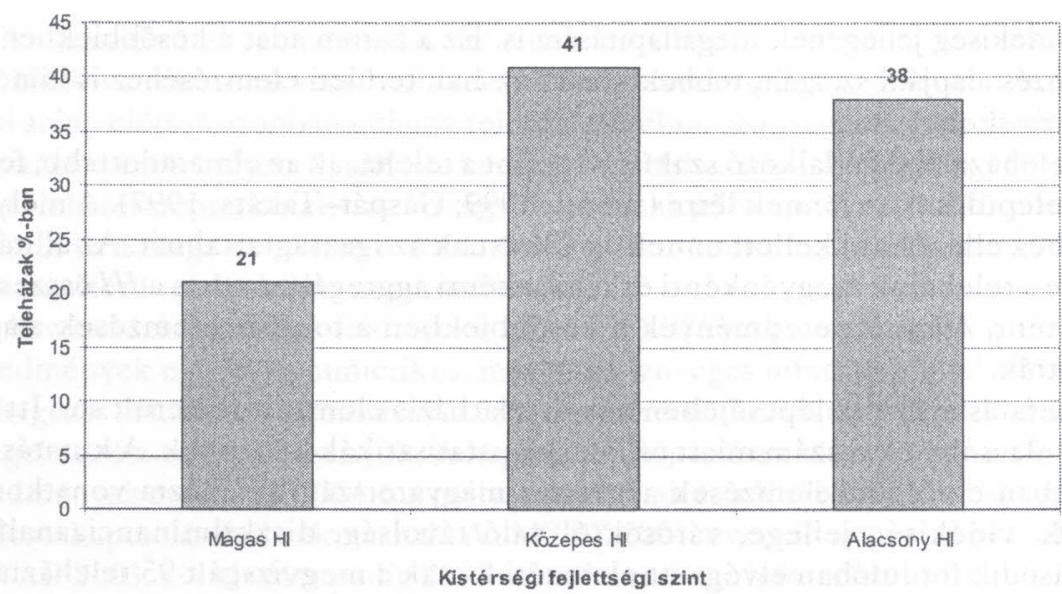

1. ábra. A teleházak \%-os megoszlása a kistérségi fejlettségi szint függvényében

Az a tény, hogy a teleházak többsége közepes és alacsony fejlettségú területen jött létre, inkább a véletlen múvének tekinthető, mint valamilyen tudatos tervezési folyamat eredményének. Ugyanakkor a nagyvárosoktól való távolság összefüggésben áll a teleházak megszúnésével. Ha egy teleház nagyvároshoz közel (30km-en belül) helyezkedik el, nagyobb az esélye annak, hogy megszúnik, mint egy olyan településen, amely nagyvárostól távol fekszik. A jelenség nem igényel különösebb magyarázatot. Magyarországon nincsenek nagy távolságok, a legtöbb település valamelyik nagyváros közelében van. A nagyváros közelsége többfélét jelenthet, például konkurenciát, magasabb fizetést, jobb életkörülményeket, tehát az emberek kevésbé vannak rászorulva a teleházra, $s$ ezért nem is veszik igénybe szolgáltatásait.

A vidékiség jellege alapján történố besorolás a következô eloszlást mutatja:

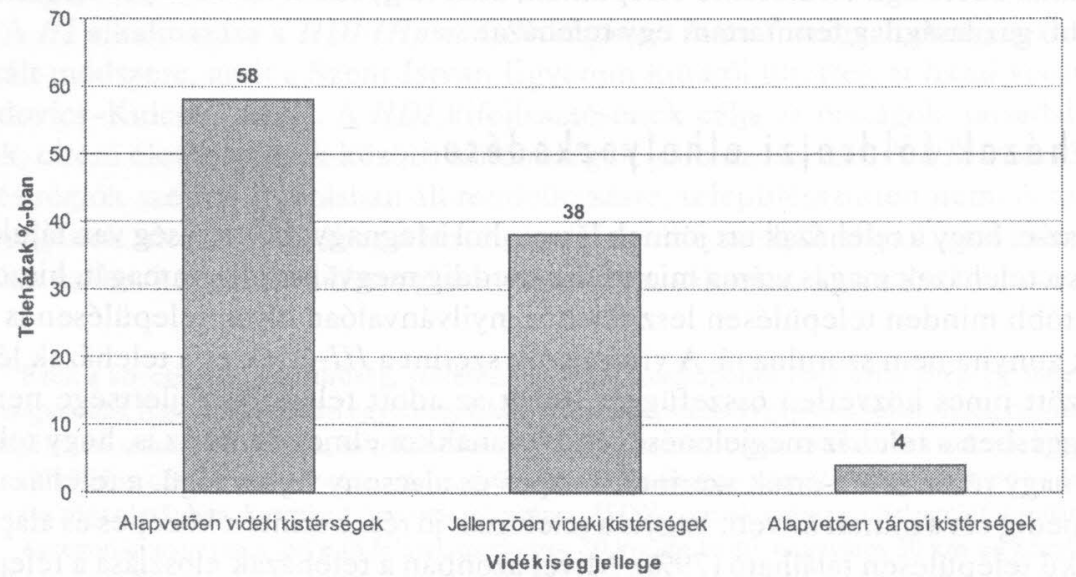

2. ábra. A vidékiség jellegének és a teleházak számának az összefüggése 
A grafikonból kitúnik, hogy a teleházakat alapvetốen vidéki és jellemzốen vidéki kistérségekben hozták létre. Alapvetôen városi kistérségekben a teleházak száma elenyészố. Az alacsony $H I$-értékkel rendelkező kistérségek $91 \%$-a alapvetôen vidéki kistérség. Ezekben a kistérségekben van a teleházak 36\%-a. Elmondható tehát, hogy a teleházak többsége valóban a rászoruló településeken található, de ennek oka nem valamilyen célzott, tudatos tervezés, hanem a puszta véletlen. Egyedül a diszkriminanciaanalízis eredményei árnyalják a képet. Az eredmények azt mutatják, hogy inkább a relatíve fiatalabb, nagyobb civil aktivitással rendelkező, kereskedelmileg, gazdaságilag aktívabb települések hoznak létre teleházat.

\section{A teleházak gazdasági fenntarthatósága}

A teleházak fenntartása és gazdasági értelemben vett fenntarthatósága a teleházak múködésének sarkalatos pontja. Mint már fentebb szó volt róla, a teleházak többsége falvakban jön létre, ahol a kereslet kicsi egy üzleti vállalkozás fenntartásához, de vajon elég-e ahhoz, hogy egy nonprofit intézmény fennmaradjon? A felmérés során megkérdezett teleházak 70\%-a tevékenységét nonprofitnak jellemezte, 20\%-uk állította magáról, hogy vegyes - egyidejúleg üzleti és nonprofit - tevékenységet folytat, míg $10 \%$-uk nem válaszolt. Ám mit jelent az, hogy nonprofit tevékenység? A nonprofit szolgáltatás elvileg azt jelenti, hogy a szolgáltatás ára csak a szolgáltatás önköltségét fedezi, tehát a szolgáltatónak nem származik belóle haszna.

Függetlenül a teleházak árképzésétól, tisztán a szolgáltatásokból származó bevételekból fenntartható-e egy teleház? A következő kérdés, hogy fenntartható-e nonprofit módon vagy üzleti módon? A válaszadók jelentôs része saját bevallása szerint nonprofit jellegú tevékenységet folytat. Nulla jövedelemmel legfeljebb stagnálni lehet jó esetben, de fejlődni nem, holott a teleházak egyik funkciója az idézett definíciók szerint az infrastruktúra biztosítása. Miból lehet ezt az infrastruktúrát fejleszteni, ha nincs rá fedezet? A vizsgálatok szerint a teleházak egyharmada a múködés elsó három évében bezár. Ám ha nonprofit jellegük dacára magasabb árat kérnek, hogy fenn tudjanak maradni, akkor nem érik el azt a célt, amiért eredetileg létrehozták óket, nevezetesen a közösségi hozzáférés biztosítását mindenki számára, azok számára is, akik szociálisan hátrányosabb helyzetben vannak. Külföldi szerzók is hangoztatják, hogy a teleházak fenntartási költségeinek egy részét ugyan a bevételük biztosítja, de a pénztárcán tátongó réseket már a támogatóknak és a partnereknek kell betömniük. A bevételorientáltság ellentétben áll a teleházak fő funkciójával, tehát a támogatás - mind magán-, mind állami forrásokból - szükségszerú (Proenza, 2001).

\section{A teleházak árképzése}

A teleházak árképzése háromféle módon történhet:

1. Nonprofit: a szolgáltatás ára csak az önköltséget fedezi.

2. Üzleti: a szolgáltatás árát üzleti alapon határozzák meg, úgy, hogy fedezi az önköltséget, és ezen felül jövedelmet is biztosít. Mivel a teleház nonprofit intézmény, a tisztán üzleti alapon történô árképzés nem a teleházak sajátja. 
3. Vegyes: a kettố kombinációja, bizonyos szolgáltatásokat önköltségi áron értékesítenek, másokat pedig üzleti alapon.

A teleházak küldetésükból adódóan alapvetôen nem profitorientált szervezetek. A felmérés szerint a megkérdezett teleházak $70 \%$-a nonprofit múködésúnek tartja magát. A gyakorlati munka során azonban olyan tapasztalatok születtek, hogy a teleházak sok esetben nem tudják pontosan meghatározni, hogy mit is jelent a nonprofit múködés. Ezért szükséges volt a teleházak árképzését összevetni a teleházvezetók által meghatározott profitorientált, illetve nem profitorientált kategóriával. A teleházak árképzésének meghatározásához négyféle szolgáltatás árai kerültek be a vizsgálatba.

A négyféle szolgáltatás a következô:

1. Géphasználat, Ft/óra

2. Internethasználat, $\mathrm{Ft}$ /óra

3. Nyomtatás, fekete-fehér, Ft/lap

4. Fénymásolás, A4, Ft/lap

A szolgáltatások árait kategorizálva, majd indexet képezve állt elô az adott teleház árkategóriája. Az indexképzés során a géphasználat és az internethasználat árait másfélszeres súlyozással számítottuk be, mert ez a két szolgáltatás alapvetố a teleházak szolgáltatásai között. A kutatás egyéb szolgáltatások árait is vizsgálta, azonban a többi szolgáltatás árai nem álltak rendelkezésre minden teleházban, így nem feleltek meg a vizsgálat szempontjából.

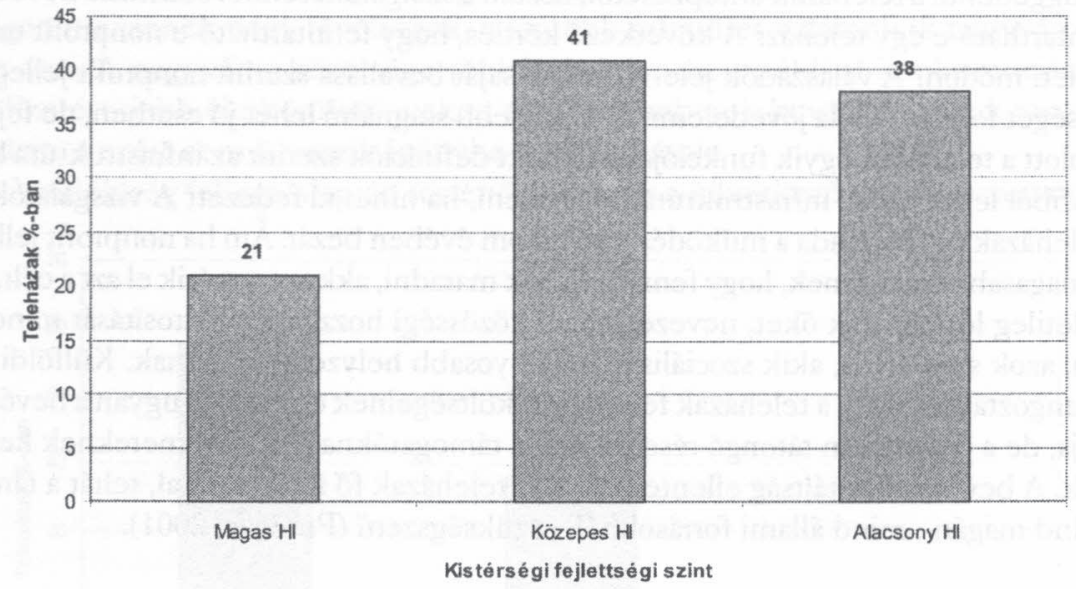

3. ábra. A megvizsgált teleházak árindex alapján történố besorolása

Az ábráról leolvasható, hogy a teleházak többsége az „olcsó” minôsítést kapta, ugyanakkor a „drágának” minôsített teleházak alig néhány százalékkal vannak kevesebben. Ár-összehasonlító elemzést nem lehetett elvégezni, mivel a teleházaknak az adott településen általában nincs konkurenciájuk, ${ }^{7}$ így nincs olyan szervezet vagy

\footnotetext{
${ }^{7}$ A megvizsgált teleházak 16 százalékának van konkurenciája, ez túlnyomórészt iskola vagy mûvelôdési ház.
} 
gazdasági vállalkozás, amellyel az összehasonlítás elvégezhető. Az árképzést és a teleházvezetốk véleményét összevetve megállapítható, hogy bár a teleházak többsége nonprofit múködésűnek vallja magát, az adott teleház árképzése és a múködési mód között nincs közvetlen összefüggés. Tehát a magát nonprofitnak valló teleházak között ugyanannyi eséllyel található drágább árszínvonalú teleház, mint olcsó. A tapasztalatok szerint ennek oka abban keresendô, hogy a teleházakra nyomás nehezedik mind a lakosság, mind a Teleház Szövetség részéról, ezért a teleházvezetốk az esetek többségében inkább nonprofit múködésúnek vallják magukat. A teleházak azonban nagyon nehezen tudnak nonprofit módon múködni, mert az elvárások nagyok, de a támogatások kicsik. Mưködésre támogatást elsősorban az önkormányzattól remélhetnek: a megvizsgált teleházak 34\%-a kap valamilyen támogatást, elsôsorban a helyi önkormányzattól.

Mivel a teleházak egyharmada kap valamilyen múködési támogatást, érdekes annak vizsgálata, hogy azok a teleházak, amelyek támogatásban részesülnek, olcsóbb árszinttel dolgoznak-e, mint a nem támogatott társaik. Az elemzés során azonban kiderült, hogy a teleházak támogatása és árszintje között nincs összefüggés. Bár a teleháznak az adott településen általában nincsenek konkurensei, az elemzés kitért annak vizsgálatára is, hogy ahol a teleháznak van konkurenciája, ott a teleház esetleg magasabb árszinttel dolgozik-e, de a vizsgálatok szerint a konkurencia megléte vagy hiánya sem befolyásolja az árszintet.

A megvizsgált teleházak többségét (kb. 51\%) civilszervezetek múködtetik. A maradékon az önkormányzat és magánszemélyek osztoznak. Feltételeztük, hogy a civil múködtetésû́ teleházak ténylegesen nonprofit múködésúek, tehát az áraik is olcsóbbak. A vizsgálatok szerint azonban a civil és az önkormányzati múködtetésú teleházak nagyjából azonos árszinttel dolgoznak, nincs nagy különbség közöttük. Sốt, néhány százaléknyi eltéréssel az önkormányzati teleházak bizonyultak olcsóbbnak, bár ez a gyakorlatban csupán egy-két teleházat jelent, tehát nem perdöntő.

Az elemzés kiterjedt annak a vizsgálatára is, hogy a teleház fizetett alkalmazottainak és önkéntes társadalmi munkásainak aránya összefügg-e az árszinttel. Feltevésünk az volt, hogy az olcsóbb árszinttel dolgozó teleházak kevesebb fizetett alkalmazottat és több társadalmi munkást foglalkoztatnak. Az eredmények szerint azonban ez sem igaz, a fizetett és a nem fizetett dolgozók létszáma és az árszint között nincs összefüggés. Vizsgáltuk a teleházak által adott kedvezményeket is. A megvizsgált teleházak $26 \%$-a ad valamilyen kedvezményt felhasználóinak, ezek jellemzóen mennyiségi kedvezmények. Teljesen ingyenes csupán néhány teleház volt. Az önkormányzati múködtetésú teleházak nagyobb arányban nyújtottak valamilyen kedvezményt felhasználóiknak, mint a civil irányításúak. Ennek hátterében vélhetốen az áll, hogy az önkormányzat nagyobb anyagi lehetôségekkel rendelkezik, ezért könnyebben tud jótékonykodni is. A kis elemszám azonban nem ad lehetôséget a komolyabb elemzésekre. A vizsgálat kitért továbbá annak elemzésére is, hogy a teleházak rendezvény-és tanfolyam-szervezési ${ }^{8}$ szokásai összefüggésben állnak-e az árszinttel, de nem találtunk ilyen jellegú kapcsolatot.

\footnotetext{
${ }^{8}$ A rendezvények köre igen tág, az ingyenes rendezvényektól (drog-prevenció, parlagfứ-gyújtés) kezdve a fizetôs rendezvényekig, tanfolyamokig (filmvetítés, bál, KRESZ-tanfolyam) terjedhet.
} 
A HI-értéket a teleházak árképzésével összevetve megállapítható, hogy a $H I$-értékek között szintén nem mutatható ki kapcsolat. Ugyanez vonatkozik a városoktól való távolságra is. Ugyanakkor a teleházak vidéki jellegének rangsora összefüggést mutat az árképzéssel. Az eredmények azt mutatják, hogy a jellemzốen vidéki és az alapvetốn vidéki kistérségekben múködik a „drágának” minősített teleházak 90\%-a („drága” minốsítést a megvizsgált teleházak valamivel több mint egyharmada kapott).

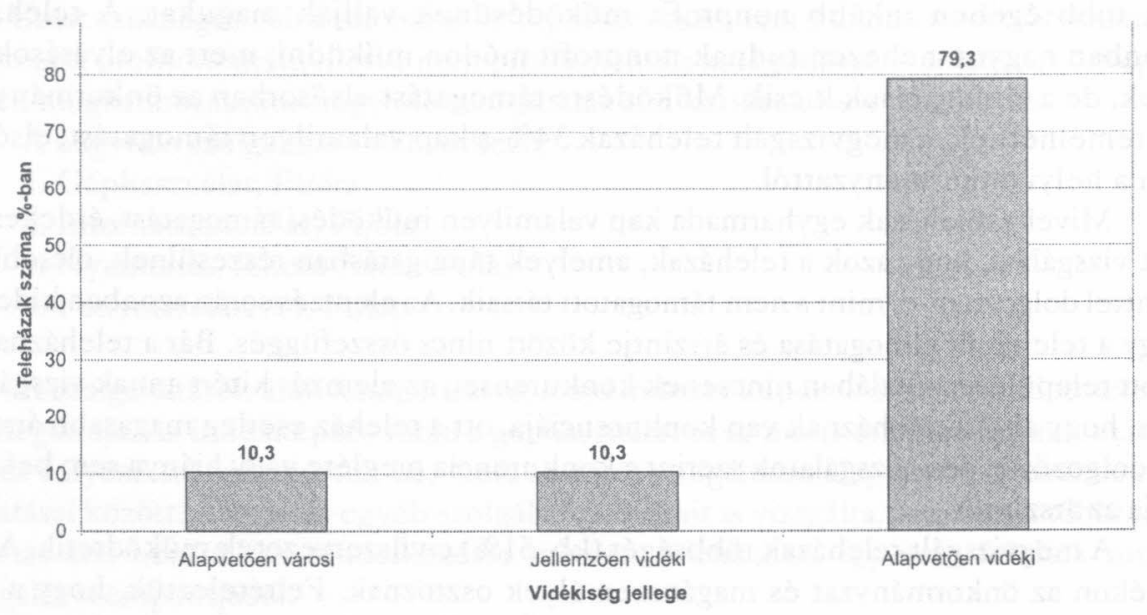

4. ábra. A vidékiség jellegének megoszlása $=38$. ÁBRA

Az eddig tárgyalt eredmények fényében az ábra úgy értelmezhetố, hogy bár az árképzés nincs összefüggésben egy sor fontos tényezővel, a földrajzi elhelyezkedés hatással van a teleházak árképzésére. Vagyis az alapvetốen vidéki kistérségekben elhelyezkedố teleházak általában véve drágább árszínvonalon múködnek, mint a többi. A helyzet teljesen érthetô, a teleházak többsége falvakban, kistelepüléseken múködik, ahol a lakosság létszáma általában kevesebb, mint amennyit a méretgazdaságosság megkíván. Ezért némileg magasabb árszínvonalon kénytelen üzemelni, mint azok a teleházak, amelyek nagyobb településeken találhatók. Az is nyilvánvalóan kiderült, hogy mivel a teleházak többségének nincs konkurenciája, így ezek nincsenek rászorítva, hogy alacsonyabb árszínvonalon múködjenek.

A teleházak megítélésénél azonban nem csak egyszerú, racionális gazdasági szempontokat kell figyelembe venni. A teleház nem tehetố egyszerú üzleti vállalkozássá, mert akkor éppen a lényegét veszítené el, legfóbb céljáról mondana le. Gazdasági vállalkozásként üzemeltetve a kistelepülések többségében egy csapásra megszúnne a teleházak nagy része, mivel a vállalkozóknak nem érné meg fenntartani óket. Ebben az esetben az ott lakók életminôsége, komfortérzete csökkenne. Ezek a szempontok tehát árnyalják a teleházak gazdasági elemzését. 


\section{Összefoglalás}

Az eredmények elemzéséból azt a következtetést lehet levonni, hogy az árszintnek tulajdonképpen csekély hatása van a teleházak múködésére. A felsorolt eredményekból kitûnik, hogy bár az árszintet számos tényezố szempontjából elemeztük, nem találtunk olyan tényezốt a teleházak múködésében, amellyel az árszint kapcsolata egyértelmúen, minden kétséget kizáróan megállapítható lenne. Az egyetlen tényező, amely hatással van a teleház árszintjére, nem belső, hanem külső tényező, nevezetesen a kistérség vidékiség jellegének besorolása. Elmondható tehát, hogy a teleházak árszintje nincs közvetlen kapcsolatban a teleházak müködésével. Ezt megerôsítik a teleházvezetốkkel készített interjúk is. Az interjúk során a teleházvezetók beszámoltak arról, hogy az árbevétel általában az összes költségek egyharmadára elegendô, a fennmaradó kétharmad részt támogatóktól és pályázati forrásokból szerzik be. Ezért a teleház árainak a teleház múködése szempontjából igen csekély a jelentôségük. Ugyanakkor a megkérdezett vezetók is rámutattak a teleházak múködésének gyenge pontjára: a teleházak helyzete és fennmaradása támogatóiktól és pályázataik sikerétól függ.

\section{Irodalom}

Bártfai Mária Erika (2002): Tudással tele ház - tudástár? http://www.inco.hu/inco8/global/cikk8h.htm\#22

Bihari Gábor (szerk.) (1999): Teleházak és távmunka Magyarországon. Teleház Kht.

Creating Rural Indicators for Shaping Territorial Policy. Paris, 1994, OECD Publication.

Erdősi Ferenc (1992): A falusi települések fejlesztése teleházak segítségével. In Telematika. Távközlési Kiadó.

Fokozódó internethasználat az alacsonyabb státuszú rétegekben. 2005. http://www.terminal.hu/newsread.php?id=30205003054407

Gáspár Mátyás - Takáts Mária (1997): Épitsünk teleházat! Magyar Teleház Szövetség.

Gáspár Mátyás (1999): Teleház Minốség Program. Csákberény.

Gáspár Mátyás és tsai (2003): Nemzeti Teleház Stratégia. Kisközösségek hálózati szolgáltatása - partnerségben. A Magyar Teleház Szövetség 2002-2006 évekre szóló stratégiáját megalapozó tervezet. Vitaanyag, módosított változat.

Hahn Csaba (2004): A térségi fejlódést befolyásoló tényezók. In Teriileti Statisztika. KSH, 2004. november, 544-564.

Kas Kinga - Larsson, Mimi (szerk.) (2001): Magyarországi teleházak monitorozása.

Laczkó Zsuzsa - Soltész Anikó (2004. október): Teleházak empirikus vizsgálata Békés, Csongrád és Bács-Kiskun megyében. In Kutatási jelentés 27-28. INFONIA Alapítvány, 118-146.

Nemes-Nagy József és tsai (2002): A teriilleti egyenlótlenségek új indikátorainak és értékelési módszereinek lehetốségei. Kutatási jelentés. VÁTI Kht.

Obádovics Csilla - Kulcsár László (2003): A vidéki népesség humánindexének alakulása Magyarországon. In Terïleti Statisztika, KSH, 2003. július, 303-323.

Proenza, Francisco J. (2001): Telecenter Sustainability: Myths and Opportunities. http://ip.cals.cornell.edu/commdev/jdc-1.cfm 